\title{
NIGERIAN STUDENTS' PERCEPTIONS AND CULTURAL MEANING CONSTRUCTION REGARDING ACADEMIC INTEGRITY IN THE ONLINE INTERNATIONAL CLASSROOM
}

\author{
AnnamariaSzilagyi [annamaria.szilagyi@ohecampus.com], Laureate Online Education, \\ Haarlerbergweg 23C, 1101 CH, Amsterdam, The Netherlands
}

\begin{abstract}
By presenting perceptions of Nigerian students enrolled in the online international postgraduate programmes of the University of Liverpool regarding academic integrity, this paper aims to explore Western ideas, such as originality and plagiarism that are extraneous in the students' local cultures. Different historical and cultural circumstances may contribute to the construction of diverse meanings that online students attribute to these concepts. The multidisciplinary study follows phenomenological research design (van Manen, 1997; Creswell, 2007) and combines cultural anthropology (Hall, 1996, Hannerz, 2001; Coleman et al., 2010) as well as online education (Anderson, 2008) in the research. The paper promotes a non-judgmental and culturally aware approach when dealing with issues of academic integrity, intends to find ideological reasons in authentic cultural belief systems that may demonstrate that the common 'nonunderstanding' concerning academic integrity is due to a culture-dependent meaning construction process, which leads to the ideological misinterpretation of these Western concepts.
\end{abstract}

Keywords: academic integrity, plagiarism, cultural anthropology, online education, Nigeria

\section{Introduction}

"It is true that men are more or less virtuous in one country or another, according to the nature of the education by which their manners and habits of life have been formed." (Machiavelli, 1517, The Discourses, 3. XLIII. p.530)

This paper explores Nigerian students' perceptions and cultural meaning construction processes in the online learning environment concerning Western concepts such as originality, academic integrity and plagiarism. It poses hypothetical questions such as whether or not the common 'non-understanding' of these notions manifests in the online learning environment and if it does, whether or not it is due to ideological differences between Western and Nigerian cultures and to the different positioning of these concepts affected by the colonial educational culture and the authentic indigenous education. The paper aims to introduce a new perspective in the perception of academic integrity and a non-judgemental, culturally sensitive way of dealing with challenges that Nigerian students face when confronted with Western requirements of criticality, argumentation and academic writing techniques in the online international postgraduate programmes.

The research project intends to highlight that originality, academic integrity, criticality and argumentation are not permanent, but context-dependent and culturally contested concepts in 
time and space. Firstly, different meanings are attributed to them in different epochs through the ideological development of Western societies. Secondly, non-Western cultures may have chosen different meanings or have not attributed any aesthetic value to these notions through the history of their authentic ideological development. Thirdly, as the Nigerian example indicates, scholars need to be aware of the influence of the British colonial culture in the history of education, which was thrown by force into the Nigerian cultural milieu; as a result, the Western colonial values may be translated by Nigerians differently and certain concepts, such as originality, criticality and academic integrity, are positioned differently in their own cultural context. Consequently, the paper intends to explore further that different ideological backgrounds and diverse interpretations of Western values result in issues with the understanding of academic integrity in the online University. Other countries with similar colonial influences may show similar tendencies when interpreting issues of academic integrity and further exploration of the subject is needed in order to understand these general tendencies.

With regard to the dimension of space in the interpretation of academic integrity, it is important to clarify the concept of Western ideologies, which do not have geographical connotations and are used in this paper to indicate ideologies practiced in countries that share the cultural traits of the Greco-Roman civilisation (Okeja, 2012). Burckhardt, a legendary nineteenth-century critic in Renaissance studies, considered Ancient Greece as the "living and ever-flowing fountain of much that is good and bad in Western culture" (Schubert, 1943, p.130). The few pages of this article certainly do not aim to draw conclusions to what extent the hundreds of great Greek and Roman philosophers made an impact on the ideological and aesthetic development of Western societies. However, they may offer new perspectives by revealing that non-Western societies are not influenced the same way by the Greco-Roman ideological heritage, and in case of Nigeria, Western ideologies were brought into education by force as part of a peculiar historical circumstance, the colonial experience. Ways of thinking and argumentation techniques, therefore, may have been manifested in different patterns, based on the different ideological backgrounds and different interpretations of colonial values. Considering the time dimension with regard to academic integrity, it is notable that before and during the time of the formation of Western ideas, such as originality, authorship and plagiarism, there were other ideological alternatives in Europe. An example would be the culture of imitation (Buelow, 1990) that in principle did not ascertain the concept of originality.

The interviews and focus group discussions of the phenomenological research (van Manen, 1997; Creswell, 2007; Hycner, 1985; Ajjawi \& Higgs, 2007) demonstrated that, these concepts are not commonly understood among Nigerian students enrolled in the online international postgraduate programmes and that their different ideological backgrounds are contributing factors to the common misinterpretations on academic integrity. The findings suggest that Nigerian cultures may have developed different meanings of these concepts, or have chosen different ways of understanding and transmitting the collective cultural knowledge (Coleman et al., 2010) to the new generations. Therefore, the paper aims to highlight that online education providers have to take into account students' diverse educational backgrounds and individual needs, implement a great variety of strategies including teaching the cultural and epistemological origin of concepts such as originality as well as reflect upon how they might become "intercultural learners" (Leask, 2006), open to learn from their students during the teaching process.

\section{Western Criticality and Argumentation and their Implications in Nigeria}

From the standpoint of cultural anthropology, culture is seen as "meanings that we create and that, in turn, create people as members of collectivities" (Coleman et al., 2010, p.7.). The process 
of cultural meaning construction allows Nigerian students in the online programmes to create diverse meanings about concepts such as criticality, argumentation, academic writing based on their own educational experiences, which combine both Western educational practices and authentic ethnic cultural values. Western education was promoted by Christian missionaries in the colonial period by the progressive suppression of indigenous cultures and beliefs in order to facilitate the adoption of foreign cultures (Anele, 2010; Madu, 1974). By ignoring the ethnic cultures of approximately 350 ethnicities in Nigeria, amongst them the dominant ethnic groups Yoruba, Igbo, Hausa - (Agulanna, 2011; Williams, 2010; Shaka, 2005), "Europeans had assumed that Black people are innately inferior to the Whites, and they did not see any point in learning the ways of an 'inferior race"' (Anele, 2010, p.41).

Strictly Western critical approaches may lead to the wrong conclusions about African people and African ways of thinking, as the historical and cultural context, in which Western philosophies are born, have an impact on the thoughts, worldviews and cultural identities (Foucault, 1970; Derrida, 1981; Hall, 1996; Coleman et al., 2010) of their creators. According to Oguejiofor (2007), neither great Western philosophers of the Enlightenment could permit themselves to disregard the surrounding cultural and historical context whilst developing their sublime philosophical ideas. In his paper he points at the Hegelian philosophy that characterized Africa as a continent without religion, freedom, law or philosophy and Africans were categorized in the level of immobility and primitiveness for not reaching the required level of spiritual consciousness. Montesquieu declares that the slavery of human beings is wrong by nature. Yet he does not consider Africans as human beings by stating that colour constitutes the essence of humanity:

"Il est...naturel de penser que c'est la couleur qui constitue l'essence de l'bumanité." (Montesquieu, cited in Oguejiofor, 2007, p.34).

Western critical thinking and argumentation are characterized by universal rationality, critical analysis, rigorous and abstract reasoning, argumentation, literacy, as well as charged with cultural values such as the importance of the individual as the source of justification - concept that emerged during the Reformation -, and the confrontation of collective instead of individual views through logical argumentation, intellectual discussion and debate (Ikuenobe, 1997, in Fasiku, 2008). Critics in contemporary African philosophy (Wiredu, 1980; Hountondji, 1983; Oladipo, 2000) point out these differentiating factors when stating that African thoughts, beliefs and worldviews may be considered pre-rational and antiscientific, as African languages are not subject of critical analysis, interpretation and clarification. Other critics (Makinde, 1983; Hallen, 1996), however, call for the re-evaluation of the intellectual heritage of African indigenous cultures by liberating them from the cross-cultural rational standards rooted in Western philosophies. For example, Hallen (1996) offers authentic ways of appreciating African philosophy from the standpoint of African languages and the peculiar meanings that these languages attribute to philosophical concepts and ideas.

\section{The Dimension of Time}

\section{Western Meanings of Originality and Academic Integrity}

Cultural identities are "never singular, but multiply constructed" and are "subject of radical historicization"; especially in the 'post-colonial' world, cultural identities cannot be regarded without the historical circumstances that affected the characteristics of their culture and people (Hall, 1996, p.4). Given this hypothesis, one may ask what the perceptions and cognition of 
Nigerian students are of notions such as academic integrity or originality and what authentic meanings they attribute to these notions. In order to investigate the meanings that Nigerian students construct for these concepts, we need to understand first of all the historical context, in which concepts such as originality and ownership were developed in Western societies.

In Western cultures, the concept of originality has a relatively short career in comparison with the culture of imitation practiced for hundreds of years in Europe. Imitation animated by the Humanistic ideology of recreating the great antique Greco-Roman world was predominant until the end of the $19^{\text {th }}$ century, and was based on the aesthetic views of classical sources such as Aristotle, Cicero and Quintilian (Buelow, 1990; Schubert, 1943; Reynolds \& Wilson, 1974). The latter teaches writers, aesthetics, philosophers and artists the following:

\section{"It is expedient to imitate whatever has been invented with success. And it is a universal role of life that we should wish to copy what we approve in others." (Quintilian, 1921, p.75., cited in Buelow, 1990, p.119)}

Until the $18^{\text {th }}$ century, no one questioned this principle, and copying was essentially acceptable and even justified in moral, ethical and aesthetic terms. Buelow (1990) points out that concepts such as originality, ownership and plagiarism were non-existent in Western cultures before. $\mathrm{He}$ highlights the fact that after centuries of Humanism, their earliest definitions surfaced in the $18^{\text {th }}$ century England, Germany and France based on $17^{\text {th }}$-century ideas of philosophers, aestheticians, writers and artists. The ideological change was not easy even in Western countries and caused many turbulences in $18^{\text {th }}$-century aesthetics, including the absurd event of Milton being accused with plagiarism for his epic poem, Paradise Lost, in which he apparently copied a Latin poem from 1654, written by Jacobus Masenius of Cologne (Buelow, 1990, p.121). The first systematic definition of originality in English aesthetics is attributed to a writer, poet, and dramatist, Edward Young (1683-1765), who summarised originality as follows:

\section{"Advance is necessary in literature as well as in science: the present must not be subservient to the past" [...] "No imitation, however great, can reach the height of the original." (Morley, 1918, cited in Buelow, 1990, p.123)}

\section{The Dimension of Space}

\section{The Impact of Indigenous Educational Values in Nigeria}

Okoro claims that education has high values in every culture and it is "not an invention brought to Africa from Europe" as "education has always been a prominent and permanent feature of life on the African continent and Nigeria in particular." (Okoro, 2011, p.235) Indigenous cultures had been developing their unique belief systems, social-hierarchical structure and authentic educational methods and transmitting these orally between generations over thousands of years (Anele, 2010). African traditional education is considered a lifelong educational model with practical orientation, using teaching/learning methods such as imitation, memorization, demonstration, recitation, ritual ceremony, proverbs, storytelling from the local history and the indigenous mythopoetic world (Kennedy, 2012; Okoro, 2011). In addition, it also focuses on values such as social responsibility, job orientation, political participation, as well as spiritual and moral values (Agulanna, 2011; Beckloff, 2008; Akinyemi, 2003).

Learning methods, such as argumentation, critical thinking, questioning the logic or analysing meanings, were traditionally discouraged as children "were to be seen, but not heard" (Okoro, 2011, p.235). This approach is based on the culture of respect for elders, which is manifested by 
silence in many ethnic cultures in Nigeria, and in some - especially in the Yoruba cultures -, it is also expressed by the act of prostration in front of elderly persons (Medubi, 2010; Adeleke, 2004). Akinyemi confirms that traditional Yoruba education aims to create an 'ideal being' called omoluábi, who is an honest, loyal, helpful social being, devoted to duty and work, attributes high respect for old age and possesses the cultural characteristics that "make a child a useful member of the community" (Akinyemi, 2003, p.163). Erigbo Mmadu is considered the Igbo version of the Yoruba 'good person' and other Nigerian ethnicities have also developed similar concepts of the ideal social being educated in the society by elders and family members within a lifelong learning model (Agulanna, 2011; Beckloff, 2008).

\section{The Impact of Colonial Education in Nigeria}

It was in the $16^{\text {th }}$ century that formal Western education was introduced in Nigeria for the first time, adapting similar European ideologies to the later implemented British colonial educational system (Okoro, 2011). With the British colonial education foreign ideologies and cultural values infiltrated the colonial society and with time, socio-economic status appeared to be linked to academic qualification, classifying the indigenous vocational and practical education as "suitable only for people of low academic quality." (Okoro, 2011, p.235)

In post-independent Nigeria, the educational model in schools retained the British educational system in all levels (Palmer, 1990). Educational reforms, schools and universities were rapidly implemented in the country: Akinyemi \& Bassey (2012) and Fakinlede (2012) reported that between 1948 and 2011 the Nigerian higher education system expanded from one (University of Ibadan-University College London) to 119, including one National Open University and four federal universities with distance education opportunities in Nigeria. During the rapid expansion there was not enough time and resource to implement efficient quality assurance and control processes and to strictly monitor academic integrity in universities, which led to the deterioration of educational standards and teaching quality (Oyogwu, 2008). Aluede, Omoregie and Osa-Edoh (2006) and Ofoegbu (2009) argue that examination malpractices (cheating, collusion, selling examination questions in advance) are a widespread phenomenon in Nigerian Universities due to the scarce funding of the educational sector. Practical constraints, such as lack of time, resources and funding may contribute to the different interpretations of academic integrity. From a cultural anthropologist point of view, there is a need for a qualitative research conducted in Nigeria that analyses teacher perceptions of academic integrity, in order to determine to what extent underlying ideological differences and cultural factors have an impact on the leniency in keeping and monitoring academic integrity.

Regarding student perceptions, the analysed literature (Babalola, 2012; Aluede, Omoregie \& OsaEdoh, 2006; Alutu \& Alutu, 2003) supports that there is a common characteristic among Nigerian students, namely the common 'non-understanding' of notions such as plagiarism or academic integrity. Babalola's study (2012) conducted in an undergraduate private Nigerian university demonstrates that most students did not have a good understanding of plagiarism and aspirations for better grades, poor knowledge of referencing rules, time pressure and easy access to information through web, which developed a 'copy-paste' culture among students, were common factors that increased the likelihood of committing plagiarism. In terms of argumentation and critical thinking strategies Ollarivaju (1986) and Okoye and Okechukwu (2012) points out that low student performance in science education in Nigerian schools is due to the traditional teaching methods that do not encourage practical scientific methods such as concept mapping and problem solving. Lack of resources and well-trained teachers as well as traditional teaching methods may contribute to this outcome. 


\section{Meaning construction in online learning environment}

In regard to plagiarism practices, the online learning environment is particularly vulnerable. Students and teachers equally perceive a higher tendency to commit plagiarism and breach academic integrity rules in the online class (Chiesl, 2007; Finkenberg, 2007). There are only limited literary sources with regard to cultural reasons that may increase the likelihood of academic integrity issues in the online class.

The successful completion of an online programme is influenced by factors such as technological knowledge, content, student motivation and "cultural representations students and teachers bring to the learning situation" (Uzuner, 2009, p.1). Interaction in a multicultural learning environment is challenging, considering the person- and context-dependent, interpretative processes that affect communication (Hannerz, 1992), therefore, online interaction as well. Students live and work in their local societies and stay physically and socially attached to their own cultures. At the same time, they exchange information with students and instructors from all over the world in the global and virtual classroom. From a cultural psychologist standpoint, (Bruner, 1996, p.X) a "cultural view of education does not really require constant cultural comparison; rather it requires that one considers education and school learning in their situated cultural context." Bruner (1996, p.3) elaborates that "although meanings are 'in the mind', they have their origins and their significance in the culture in which they are created". As meanings are culturally constructed in every human being, online interaction may result in the misinterpretation of meanings between culturally diverse learners and teachers in the global and virtual classroom (Anderson, 2008).

\section{Methodology}

The findings are part of a wider research project that focuses on the online learning experience of Nigerian students and follows phenomenological principles (van Manen, 1997; Crotty, 1998; Creswell, 2007; Mason, 2012) in the research design. Hermeneutic phenomenology is oriented towards lived experience by interpreting the 'texts' of life (van Manen, 1997). The data generation process provided in-depth narratives, rich textual descriptions about the phenomenon, which lead to deeper reflection and multi-layered understanding of the online learning experience (Smith, 1983; Ajjawi \& Higgs, 2007). 17 Nigerian students were interviewed and another 12 participated in the focus group discussion. The participants are enrolled or graduated from the online master and doctoral programmes of the University of Liverpool delivered by Laureate Online Education. The selected students were all Nigerian citizens and had at least 1 year learning experience in the online programme. The participants were chosen after consulting with their personal Student Support Manager about their character, as it was important to interview students who are talkative, not afraid of expressing their thoughts and dedicated to the purpose of the research. A mixed group of student was selected: some participants received official warnings from the online University and were under investigation for breaching the academic integrity policy in place, others did not have such academic records and managed to succeed in the online programme without official warnings.

After researchers received the ethical approval from the University, students were asked to sign the consent form, which informed them about the aim and objectives of the research, the structure of the interview/focus group and that their answers would be recorded. The semistructured interviews were organized either face-to-face or via Skype; the focus group discussion occurred in the course of a face-to-face event in Liverpool. Phone or face-to-face interviews were more efficient than email correspondence: simply answering the interview questions without additional guiding questions from the researcher, the email answers would have been less of in- 
depth quality, hence the researcher avoided this option as much as possible in order to generate more quality data.

Participants are in their thirties and forties, and the majority of them live in the Southern regions, whereas some in the Northern parts of Nigeria. The interview structure focused on three main topics: cultural values at home, online learning experience and face-to-face learning experience in the Nigerian public higher educational system. The interview and focus group protocol covered the following set of questions that invited students to reflect upon their culture and online learning challenges:

- What are the basic values of your culture? If you share these values, how do they manifest in your communication style?

- How is your relationship with your parents? What did you learn from them? How did they raise you as a child? Do you share their beliefs? Is there any difference between yours and your parents' views?

- What is your experience with online learning?

- How could you describe the conditions, contexts, situations that affected your online learning experience?

- What feelings come to your mind when thinking about online learning?

- What meaning does online learning have in your life? What are your goals with online learning?

- How could you describe a successful online learner?

- What were your expectations when you started the online programme?

It is interesting to note that after reflecting upon these generic questions, almost every interviewee and participant of the focus group discussion contemplated upon academic integrity issues and recalled challenges with understanding and dealing with plagiarism. These are described in detail in the Findings section of this paper. The interviews and focus group session were transcribed and analysed with rigorous phenomenological research methods (Hycner, 1985; Ajjawi \& Higgs, 2007). Summaries were prepared from the transcripts for data validation purposes and sent back to the participants who gave their consent or suggested small changes via email. The transcripts were coded in NVivo and the eventual bracketing phase started with the identification of units of meanings categorized in themes and sub-themes. Continuous selfreflection, cultural self-awareness, regular consultation with experienced researchers in phenomenology and cultural studies as well as frequent cross-checks with the critical literature ensured faithfulness to the data.

\section{Findings}

Many Nigerian students chose online learning with a British university due to the international reputation of the institution and the usage of English language which is the official language of education in Nigeria. The findings show that most of the Nigerian students start their online master or doctoral studies unprepared in terms of understanding and applying the Western referencing rules implemented in the online international programmes. The themes that emerged in the course of the data analysis confirm that in the students' previous studies mostly in Nigeria, active participation in the discussions, free expression of critical thoughts, research with academic rigor were not strictly required or monitored. Therefore, their attitude towards academic integrity and referencing, their academic writing and critical thinking skills were not challenged with enough scrutiny that would have prepared them to successfully face the challenges of the online master and doctoral programmes of the University of Liverpool. 


\section{"[In Nigeria] you are not encouraged to research" (Student 4)}

"You are not encouraged to learn, expand your horizon, or give your own point of view" (Student 4). When students compared their previous undergraduate and master studies in Nigeria with the online master studies based on Western-type learning and teaching methods, it became evident that their experience in the Nigerian educational system was significantly different in terms of developing critical thinking skills, research rigor, asking probing questions from the teacher or voicing one's opinion freely:

"Unfortunately, our educational system is as bad as everything else in Nigeria. It's been neglected. We are more into the old day's method of teaching where the lecturer reads notes that he prepared and he dictates to the class. Students copy it down, make notes, memorize it, come back and write an exam. You're not encouraged to research; you're not encouraged to learn, expand your horizon, or give your own point of view. You dare not to challenge a teacher's belief. You are expected to learn from him what he has decided to teach you. I think the Nigerian method of teaching is limited." (Student 4, MSc in Forensic Psychology, 4 modules completed)

In other words, they are used to copying the teacher's words and simply reiterating it in oral exams or written assignments. The attitude of "not daring to challenge the teacher" and copying his/her words relate to a wider cultural phenomenon in the Nigerian society: the respect for elders and authoritative figures that may be manifested by remaining in silence. Under certain circumstances, the questioning of the elders' opinion is considered disrespectful and rude. One's opinion cannot be expressed, unless permission is granted by the elderly or authoritative person (Agulanna, 2011; Medubi, 2010; Akinyemi, 2003). The cultural communicative norms and the post-independent Nigerian educational model (Okoye \& Okechukwu, 2012; Novak, 1990; Ollarivaju, 1986) that do not encourage critical thinking and questioning pose a challenge for Nigerian students who have aspirations to study at Western-type online institutions. The successful students come to understand from the first module of the online programme that they are "expected to be critical, justify [their] choices and voice [their] views" (Student 9, Master in Public Health Programme, graduated); others may be discouraged, decide to drop the course altogether and find their luck somewhere else.

\section{"Referencing was a new concept to me. It was the first for me with Liverpool" (Student 6)}

“I didn't have to do a lot of referencing" (Student 7). Management programmes attract students of diverse educational backgrounds, which is a contributing factor to the challenging nature of learning online and using strict referencing rules. 8 out of the 17 interviewed master and doctoral students had previously studied different disciplines, such as Medicine, Microbiology, Public Health or Engineering, on an undergraduate or master level. They were motivated to enrol in the online management programmes on master or doctoral level to diversify their skills and fulfil the demands of the highly competitive Nigerian labour market. They stated that the University of Liverpool was the first institution where they learnt how to reference an academic paper:

"[...] it was microbiology; I had a lot of lab time, doing experiments for my final project. Some days you had lectures all day. But the amount of research that I'm doing now, I didn't do it then. It wasn't an online thing and I didn't have to do a lot of referencing or resourcing. There was a classroom environment, there was a practical aspect, and there were the exams. My final project was based on an experiment of finding out, whether a particular fruit had 
certain characteristics or not. And then I wrote it down. I didn't do as much library research as I'm doing now."(Student 7, MBA Programme)

“My previous learning did not require referencing” (Student 2). Smart students discover that referencing is important in essay writing, but many of them ignore the fact that referencing is necessary also in the follow-up discussions: in a regular face-to-face seminar, students do not necessarily follow referencing rules and they need to be reminded that the moment they write down their thoughts, it is traceable and has more weight than the oral discussion. Students also mentioned that during their earlier studies, they did not have to submit many written assignments, only in every couple of months, whereas in the online programmes, they have 3,4 or more written assignments each week, which requires strong academic writing skills, including the proper usage of the applied referencing system:

"My previous learnings did not require referencing. [...] Liverpool was the first place where I was really exposed to intensive referencing on every module that I had to sit." (Student 2, graduated in MSc in International Management, previous studies in Medicine)

"IIn Nigeria] we were not really penalised. I'd answer the questions and submit my assignment. If it's right, they mark it without really querying me for not citing references or not using Harvard style. I had to learn that here. I never knew anything about plagiarism. I never knew that it was a crime; that it was bad for me to read, understand, copy and paste. I never knew that. So when I realised I [said] 'What the hell!'” (Student 8, graduated in MSc in Human Resources, previous studies in Microbiology)

Referencing was a new concept to me" (Student 6). Student 6 (MBA Programme, previous studies in Business Administration) had two plagiarism warnings until he comprehended, learnt and managed to reference correctly. Nigerian students have limited or no experience with referencing and they often underestimate the importance of accurate citation and referencing until they receive an official plagiarism warning from the University:
"[...] the first time it happened, I didn't quite understand, referencing was a new concept to me. How to reference? I thought referencing meant I should make sure I have just about 30\% of my work from internet sources [.....It's like when you buy a new laptop you need to go through the rules and regulations. Everybody gets a manual but how many people get to read all of it except when something goes wrong. Then you go to that particular part of a manual and read exactly what went wrong." (Student 6, MBA Programme)

Student 6, who had no experience with online education and had studied previously in Nigerian and South African institutions, reported that referencing was not required so strictly in his previous studies and it was used only in the final project, as it was a requirement for the awarding of the degree. He admitted that the Nigerian institutions might have improved in monitoring academic honesty since he had finished his studies, but at the time of his master studies in Nigeria (10 years ago), teachers did not pay too much attention to referencing. Indeed, the literature confirms that examination malpractices and academic integrity issues cause significant problems in the Nigerian educational system and the quality assurance and monitoring of academic dishonesty needs further development (Babalola, 2012; Aluede, Omoregie \& OsaEdoh, 2006; Alutu \& Alutu, 2003). The poor preparedness of Nigerian students in regard to academic integrity is a result of a mixture of practical constraints and traditional teaching methods that may be influenced by the local cultures, and further qualitative research is needed in order to determine how and to what extent these factors make an impact on students' performance in their previous studies in Nigeria. 


\section{"You have to write it the way it is supposed to be" (Student 11)}

Others, who already had some knowledge about referencing, were struggling with the accuracy and scrutiny of closely adhering to the accepted referencing style that the University of Liverpool requires from every student:

"In Nigeria], even if I don't know what to do [what is the right format], and I say I copied
this from X.Y., 2011, whether in the right format or not, there is intention to acknowledge?
But whether it is done exactly the way it's supposed to be is a different ballgame. I discovered
that in the online [programme], the one I've just completed, it's not just writing where you got
it from, you have to write it the way it is supposed to be." (Student 11, MSc in Operations
and Supply Chain Management, previous studies in MBA in Project Management)

This finding indicates that once the problem is understood, there is a learning curve concerning how to apply citation and reference in practice, which includes learning from mistakes. Students may already be aware of the referencing rules, but can easily accumulate plagiarism charges, simply because they are still learning how to apply them. Since the interviews were taken place, the University of Liverpool and the institution in partnership with the University have made significant changes in their policy on academic integrity which allows students to go through a learning curve and encourages them to learn from mistake.

\section{"I've got curious, what is exactly that these people want" (Student 14)}

“The plagiarism warning was the turning point, when I said 'no"' (Student 14). Similarly, students, who had previous experience in Western-type educational environment, also reported serious challenges with referencing. Even if they had some knowledge about referencing, they were not perfectly aware of every detail, did not assign too much importance to the issue, and underestimated its severity. Student 14 reported that the turning point was the moment when he received an official plagiarism warning from the University.
"[The plagiarism warning] was the turning point when I said 'no'. I got curious, what is exactly that these people want. They were really detailed. Although I read the referencing before, I went then in real details. I became, more committed because I invested a lot of time, energy and money to then allow the issue of paraphrasing and referencing to destroy everything." (Student 14, in dissertation phase, MSc in International Management programme, previous studies in Western institutions, in the field of Business Management)

In those cases, where the reason for disregarding the referencing rules is simply the lack of attention, although the concept of plagiarism is already well understood, the plagiarism warnings and penalties may serve as motivating factors that force students to fill the gaps and learn to apply the strict rules. However, the plagiarism warning is even more shocking for those who did not have a real foundation of Western concepts such as academic integrity, authorship and plagiarism. The example below illustrates what happens in a student's mind when trying to understand what is going on.

\section{"I had to defend plagiarism two times without understanding what I was defending" (Focus group participant)}

"I was ready to quit" (focus group participant). Some students were out of school for a long time and simply forgot how to reference or have never learnt strict referencing rules. When they faced the initial challenges of referencing, many of them considered dropping the programme, 
because it was not something they expected. Those, who eventually stayed in the programme, noted that they had to pass several modules until they got it right and felt comfortable in the new online learning culture:

\begin{abstract}
"When I started the program, I was just about 19 years out of school. At that time of my first degree, there were no computers, there was no online referencing. So doing online referencing was very new to me. And that's where my instructor came in, always hitting me with plagiarism. I had to defend plagiarism two times without understanding what I was defending. [...] At the time I wrote him [my instructor] a mail and I said: Do you think I should continue with this program? Because it's been 19 years I left formal education. And I don't think you can teach an old dog new tricks... Then he replied and said, I suggest that you continue and take the corrections'. Because I was ready to quit. Because that was my very first module. Well, I was surprised when I finished the module and I got a C. I said OK, since I didn't fail, let's go...I was at the time [of the second module, when] I really understood what was expected of me. In my first module I didn't understand what was expected." (Female, graduate student, focus group discussion)
\end{abstract}

Academic integrity and the strict referencing culture is a shocking experience for Nigerian students at the beginning of the programme, and it takes several modules until they understand how to apply it properly. A similar, still ongoing research project (Szilagyi, unpublished) shows similarities with students from other locations, (e.g. Middle East). Each interview and focus group participant remembered the initial challenges faced with referencing, which they never expected, as they were not aware of the importance of academic integrity in Western cultures. They entered the first module without proper preparation or a sound cultural and ideological foundation about the Western notion of plagiarism.

\title{
"It was not something I was prepared to accept" (Student 9)
}

“Culturally we believe in honesty and integrity" (Student 9). In the mind set of Nigerian students academic integrity appears to be linked to deeply rooted, cultural values such as personal integrity and honesty. If a plagiarism warning is received during the first module, even if it is withdrawn later, it is an extremely demoralizing experience for Nigerian students, which can lead to dropping out from the entire programme. A student commented that she was wrongly accused of plagiarism in the middle of the course, and added that if it had occurred earlier, in the first modules, she would certainly have left the programme, just like her friend did, when he experienced a similar incident at the beginning of the programme:

"If it had happened in my first or second module, as a Nigerian, and maybe a Yoruba person, I would have walked out and stopped completely. But because it wasn't my first I had the courage. [...] I was concerned and I was upset. But I was also able to deal with it because I wrote her [the instructor] back and told her exactly what I felt. I said Look I don't cheat'.[...] Culturally we believe in honesty and integrity. But I took it seriously [because of] the mere thought of her accusing me. My integrity is very important. In the Yoruba culture there is an adage that a child that lies will steal. A child that lies will steal it's said in Yoruba, and a child that steals will commit adultery. So scaling it up, any mark on your integrity is bad and it can go further. So if you are a liar you can also be very easily called a thief. You can also be very easily called an adulteress and even a murderer. So [...] telling me that I lied or cheated, I took it very seriously because even though the percentage was low and she 
later realised that the accusation was false, it was not something I was prepared to accept."

(Student 9: female Yoruba student, UK, graduated, Master in Public Health Programme)

A false accusation of academic integrity may lead to a chain reaction involving personal integrity and honesty, reaching the point of being accused a cheater, a liar, an adulterer, or even a murderer.

\section{"It is a skill that I need to learn... It cost me two modules until I changed my mind set" (Student 14)}

I wasn't doing it correctly, even when I was aware of it." (Student 14) When the plagiarism charge is understood with all its consequences, and students comprehend that without correct referencing, they will not be successful in the Western institution, the learning process and the practical application of referencing rules do not happen in one day. One student reported that he failed two modules due to referencing issues and collected two plagiarism charges until he managed to change his mind set:

\section{"I knew that plagiarism is an offence [and] I was cautious to working [on] myself. [But] I still got the warnings. I have not paraphrased myself. I was still plagiarising. I wasn't doing it correctly, even when I was aware of it. So it is [a] skill that I need to learn. That was the frustrating part of the story.[...]The Harvard referencing is tricky to follow and until I changed my mind set, it cost me two modules." (Student 14, MSc in International Management programme, previous studies in Western institutions, in the field of Business Management)}

These findings raise questions about the learning experience of students who are not accustomed to specific interpretations of plagiarism: during their student experience they go through an ideological transformation, a "change in their mind set" when trying to acculturate to the Western ways of thinking with regard to academic integrity and plagiarism.

\section{Discussion}

The findings show that critical thinking, questioning and argumentation practices were not common characteristics of the previous educational experience of Nigerian students: they were rather discouraged to ask questions, and got used to listening to the teacher, making notes and reiterating in exams what they heard. Upon entering the online program, they have limited understanding of Western concepts, such as originality and plagiarism, although there are individual differences based on the discipline they studied before and the amount of years spent away from the academic world. The research also showed that in fact academic integrity issues were not strictly monitored during their previous studies in Nigerian universities. As they never learnt these concepts in their authentic cultural, historical and socio-economic context, the Western institution was the first that introduced the Western meanings of these notions to them. In an effort to adjust to the Western academic requirements, they constructed different meanings around these concepts, contextualized and translated them into their own cultural context. The most authentic examples of the meaning construction process are expressed in the focus group discussion, which confirms that students had a common 'non-understanding' of the concept of academic integrity and plagiarism. It is also remarkable to analyse the narrative of Student 9, who interpreted the false plagiarism accusation as an attack on her personal integrity, worldview and identity by classifying her as a cheater, liar, adulteress or even murderer. 
Appreciating the specific historical and epistemological background of Western concepts, such as originality, may help to understand that the Western way of ideological development is just one option among the many alternatives offered by the immense variety of cultures existing in the world. Authorship, originality and plagiarism are relatively modern, merely about 300-year-old aesthetic concepts in the Western world, emerged at the time of the industrial revolution when innovation could generate significant wealth. There were times when their relevance was not so obvious for Western writers, philosophers and aesthetics, let alone the academic world. These concepts emerged during a time period, in which there were other alternatives equally strong and important that could have competed with them. Therefore, the existence and development of such ideas (i.e. authorship, originality and plagiarism) are interconnected with specific historical and cultural circumstances that provided fertile grounds to these ideas, enabling them to flourish and have a great career in academia. Who knows what kind of rules and policies would be in place in the Western academic world, if the humanistic culture of imitation continued to dominate the thoughts of European intellectual circles? Then again, what happened to other cultures, which developed either authentically similar or by any chance, extremely different ideologies in their own historical and cultural contexts? Did they develop different ways of appreciating the accumulated cultural knowledge base and transmitting this from one generation to the next?

Nigerian 'ethno-philosophies', which are part of the communal and oral heritage of African cultures and are in essence generalizations about traditional worldviews of African people, are not regarded as philosophies in the 'Western' sense, unless they are subject of critical analysis, interpretation and clarification and therefore have less space in academia (Okeja, 2012). Nigerian universities follow a tendency of educating their students to respect Western ideologies and academic values with less emphasis on finding authentic African ways of criticality and argumentation (Okoye \& Okechukwu, 2012; Novak, 1990; Ollarivaju, 1986). It is arguable, however, how Western ideas, such as originality, critical thinking, academic integrity and plagiarism, can be translated and understood, whilst due to different ideological and philosophical grounds, their own authentic ideologies seem to be untranslatable into Western philosophical terms. Shall one witness in time the creation of an authentic Nigerian way of academic writing? Due to the limitations of this study, the present paper does not intend to answer these philosophical questions, but aims to highlight that there may be different types of academic writing, criticality and argumentation practices across cultures yet to be explored in academia.

Considering the tendency of globalizing education involving masses of students from cultures that follow different educational patterns in their ideology, one may ask whether or not it is sustainable to keep the rigid Western definitions of originality and academic integrity. Western aesthetic concepts are not static, but transform in time and in space according to the specific historical and cultural context. In the past, the transformation of aesthetic concepts was relatively slow and required centuries until new definitions were fully implemented in the collective cultural identity of a society. However, globalization creates fertile grounds for knowledge exchange and accelerates the meaning construction process (Hannerz, 2001). The alarming number of plagiarism incidents and breaches of academic integrity in the global academic world, in which online education appears to be even more vulnerable, indicate the emergence of a new aesthetic crisis, similar to the one that occurred in the $18^{\text {th }}$ century. This alarming phenomenon compels scholars, philosophers and higher education providers of the present and future to find new, authentic, non-judgemental, culturally aware policies that support students from different cultures in the application of the learnt knowledge within their own cultural context, with the appreciation of their own ideological and cultural values. 


\section{Conclusion}

The findings clearly demonstrated that there is a common 'non-understanding' of Western concepts, such as originality and academic integrity, among Nigerian online learners and their inability to give an authentic definition of these concepts raise questions whether these concepts are absent from their ideological heritage. The colonial educational background and the educational reforms in post-independent Nigeria aimed to establish Western norms and ideologies in academia, but the success of their implementation is questionable.

Leask (2006) and Scollon (1995) point out that diverse educational backgrounds and individual needs have to be taken into account and a great variety of strategies are needed, which include teaching the social, cultural and epistemological origins of concepts such as originality and plagiarism. Students, whose culture has ideological backgrounds that are distant from Western ideologies, will need to learn more complex academic skills than those who are familiar with the Western idea of academic integrity. The adjustment will require efforts that involve implementing changes in deeper cultural layers such as worldviews, beliefs and cultural identity.

Following the Gramscian idea of "cultural hegemony" (Gramsci, 1971) that appears when a dominant group's assumptions are accepted and extended to a wider community of people, online education providers should reflect upon how they might become "intercultural learners" (Leask, 2006) and change the way they think and behave when facing culturally diverse student needs.

Nigerian students who chose to study online in a Western University accept Western education with its concepts and policies based in Western academic culture. However, their learning behaviours follow different cultural patterns and unconsciously they might follow learning attitudes that were successful in their previous learning experience in Nigeria (Fakinlede, 2012; Sofowora, 2012; Uzuner, 2009; Anderson, 2008; Hannerz, 1992). When dealing with a multicultural student population, Western institutions need to realize that concepts such as academic integrity and plagiarism are culturally contested. As such, Western Universities have the moral responsibility to understand where their students come from and what they learnt during their previous studies with the aim of helping them how to learn and be successful in a Western educational environment (Anderson, 2008; Leask, 2006; Hall, 1996; Scollon, 1995). A culturally sensitive approach will allow a more differentiated and personalized student support that focuses on individual student needs. Consequently, the educational provider could facilitate the adjustment process by preparing a toolkit that includes introductory courses to Western educational culture, interactive online tutorials and a more intensive and personalized academic support at the beginning of studies that identifies gaps and misunderstandings in the students' knowledge base. The personalized support will facilitate the understanding of Western concepts such as academic integrity and plagiarism and improve students' critical thinking and academic writing skills. Moreover, from a business perspective, being "intercultural learners" (Leask, 2006) is not only a responsibility of instructors that teach in single modules, but has to infiltrate the areas of marketing, sales, product management, academic delivery, student administration and support. The introduction of Western academic values prior to the beginning of studies may help set up right expectations and enable students to make an informed decision about their studies. 


\section{Reference}

1. Adeleke, D. (2004). Lesson from Yoruba Mithology. In Journal of Asian and African Studies, 39(3), (pp. 179-191).

2. Agulanna, C. (2010). Community and Human Well-being in an African Culture. In Trames: Journal of the Humanities \& Social Sciences, 14(64/59) (3), (pp. 282-298).

3. Agulanna, C. (2011). Ezigbo Mmadu: An Exploration of the Igbo Concept of a Good Person. In The Journal of Pan-African Studies, 4(5), (pp. 139-161).

4. Ajjawi, R. and Higgs, J. (2007). Using Hermeneutic Phenomenology to Investigate How Experienced Practitioners Learn to Communicate Clinical Reasoning. In The Qualitative Report, 12(4), (pp. 612-638).

5. Akinyemi, A. (2003). Yoruba Oral Literature: A Source of Indigenous Education for Children. In Journal of African Cultural Studies, 16(2), (pp. 161-179).

6. Akinyemi, S. and Bassey, O.I. (2012). Planning and Funding of Higher Education in Nigeria: The Challenges. In International Education Studies, 5(4), (pp. 86-95).

7. Ally, M. (2008). Foundation of Educational Theory for Online Learning. In T. Anderson (ed.), Theory and Practice of Online Learning, (pp. 15-44). 2nd ed. Canada: AU Press, Marquis Book Printing.

8. Aluede, O.; Omoregie, E.O. and Osa-Edoh, G.I. (2006). Academic Dishonesty as a Contemporary Problem in Higher Education: How Academic Advisors Can Help. In Reading Improvement, (pp. 97-106).

9. Alutu, E.O. and Alutu, A.N.G. (2003). Examination Malpractice among Undergraduates of a Nigerian University: Implications for Academic Advising. In Guidance \& Conunselling, 18, (pp. 149-152).

10. Anderson, T. (2008). Towards a Theory of Online Learning. In T. Anderson (ed.), Theory and Practice of Online Learning. 2nd ed, Canada: Marquis Book Printing.

11. Anele, D. (2010). Western Technical Civilization and Regional Cultures in Nigeria: the Igbo Experience. In Cultura: International Journal of Pbilosophy of Culture \& Axiology, 7(2), (pp. 38-53).

12. Armer, M. and Youtz, R. (1971). Formal Education and Individual Modernity in an African Society. In American Journal of Sociology, 76(4), (pp. 604-626).

13. Babalola, Y.T. (2012). Awareness and Incidence of Plagiarism among Undergraduates in a Nigerian Private University. In African Journal of Library, Archives \& Information Science, 22(1), (pp. 53-60).

14. Beckloff, R. (2008). Cross-Cultural Perspectives on Adult Development: Implications for Adult Education in Africa. In Convergence, 41(2-3), (pp. 13-26).

15. Bruner, J. (1996). The Culture of Education. Cambridge, MA: Harvard University Press.

16. Buelow, G. (1990). Originality, Genius, Plagiarism in English Criticism of the Eighteen Century. In International Review of Aesthetics and Sociology of Music, 21(2), (pp. 117-128).

17. Chiesl, N. (2007). Pragmatic Methods to Reduce Dishonesty in Web-Based Courses. In The Quarterly Review of Distance Education, 8(3), (pp. 203-211).

18. Colaizzi, P. (1978). Reflection and research in psychology: A phenomenological study of learning. Dubuque, IA: Kendall/Hunt. 
19. Coleman, W.D.; Szeman, I. and Rethmann, P. (2010). Introduction: Cultural Autonomy, Politics, and Global Capitalism. In W.S. Coleman (ed.), Cultural Autonomy. Frictions and Connections, (pp. 1-27). Vancouver, Toronto: UBC Press.

20. Creswell, J. (2007). Qualitative Inquiry \& Research Design. Choosing Among Five Approaches (2nd Edition ed.). Thousand Oaks, London, New Delhi: Sage.

21. Crotty, M. (1998). The foundation of social research: Meaning and perspective in the research process. Sidney, New South Wales, Australia: Allen \& Unwin.

22. de Castell, S.; Bryson, S. and Jenson, J. (2002). Object lessons: Towards and educational theory of technology. In First Monday, 7(1). Available online at http://www.firstmonday.org/ojs/index.php/fm/article/view/923/845

23. Derrida, J. (1981). Positions. Chicago: University of Chicago Press.

24. Fakinlede, C. (2012). Cross-Border Distance Education in a Wired World: The Experience of a Student in Nigeria. In Turkish Online Journal of Distance Education - TOJDE, 13(4), (pp. 309319).

25. Fasiku, G. (2008). African Philolophy and the Method of Ordinary Language Philosophy. In The Journal of Pan African Studies, 2(3), (pp. 100-116).

26. Finkenberg, M. (2007). Technology. Issues Related to Online Teaching, Plagiarism and Plagiarism Detection. In Chronicle of Kinesiology \& Physical Education in Higher Education, (pp. 1617).

27. Foucault, M. (1972). The archaeology of knowledge. (A.M. Sheridan Smith, Trans.) London: Routledge.

28. Gramsci, A. (1971). Selections from the prison notebooks. London: Lawrence and Wishart.

29. Hall, S. (1996). Introduction. In S. Hall, \& P. du Gay (eds.), Questions of Cultural Identity. London, Thousand Oaks, New Delhi: Sage.

30. Hallen, B. (1996). Does it Matter Wether Linguistic Philosophy Intersects Ethnophilosophy? In APA Newslettes, A Publication of the American Philospibical Association, 96(1).

31. Hannerz, U. (1992). Cultural complexity: Studies in the social organization of meaning. New York: Columbia University Press.

32. Hannerz, U. (2001). Thinking about culture in a global ecumene. In J. Lull (ed.), Culture in the communication age, (pp. 54-71). London: Routledge.

33. Hountondji, P. (1983). African philosophy: myth and reality. Bloomington.

34. Hycner, R. (1985). Some guidelines for the phenomenological analysis of interview data. In Human Studies, 8, (pp. 279-303).

35. Kennedy, O. (2012). Philosophical and Sociological Overview of Vocational Technical Education in Nigeria. In College Student Journal, (pp. 274-282).

36. Leask, B. (2006). Plagiarism, cultural diversity and metaphor - implications for academic staff development. In Assessment \& Evaluation in Higher Education, 31(2), (pp. 183-199).

37. Machiavelli, N. (1517). The Prince and Discourses on the First Ten Books of Titus Livius. Translation, published 1950 by Christian Detmold, New York.

38. Madu, O. (1974). The School System and the Social Development of Nigeria. In proceedings of VIII World Conference of Sociology, Round Table 10: Functions of School Systems, (pp. 3-23).

Toronto, Ontario. 
39. Makinde, A. (1983). African philosophy, culture and traditional medicine. Bloomington.

40. Mason, J. (2012). Qualitative Researching. (2nd ed) London: Sage.

41. Medubi, O. (2010). A cross-cultural study of silence in Nigeria - an ethnological ethnolinguistic approach. In Journal of Multicultural Discourses, 5(1), (pp. 27-44).

42. Montesquieu. (1956). De l'esprit des lois. Paris: Garnier Freres.

43. Novak, J. (1990). Concept-mapping, a useful tool for science education. In Journal of Research in Science Teaching, 7(10), 937-949.

44. Ofoegbu, F.I. (2009). Students Perception of the Role of Parents in Academia and Continued Examination Malpractice. In Education, 129(3), (pp. 413-424).

45. Oguejiofor, J. (2007). The Enlightment Gaze: Africans in the Mind of Western Philosophy. In Philosophia Africana, 10(1), (pp. 31-36).

46. Ojogwu, C. (2008). Ethical Crisis in the Nigerian Educational System: A Challenge to Educational Administration and Parents. In College Student Journal, 42(2), (pp. 593-602).

47. Okeja, U. (2012). Space Contestations and the Teaching of African Philosophy in African Universities. In South African Journal of Philosophy, 31(4), (pp. 664-675).

48. Okoro, N. (2011). Comparative Analysis of Nigerian Educational System. In International Journal of Business and Social Science, 2(21), (pp. 234-238).

49. Okoye, N.S. and Okechukwu, R.N. (2012). The Effect of Concept Mapping and Problem Solving Teaching Strategies on Achievement in Biology among Nigerian Secondary School Students. In Education, 131(2), (pp. 288-294).

50. Oladipo, S. (2000). The Idea of African Philosophy. Ibadan: Hope Publications.

51. Ollarivaju, A. (1986). Students Under Achievement in Science and Some Remedies. In proceedings of 27th Edition of STAN, (pp. 143-147).

52. Palmer, W. (1990). Nationhood and Education in Nigeria: A Case Study of School Inspection in Nigeria as a Mean of Increasing Central Government Control. Nationhood, Internationalism and Education. In proceedings of the Eighteenth Annual Conference of the Australian and New Zealand Comparative and International Education Society, 3-5 December, (pp. 171184). University of Auckland, New Zealand: O'Rorke Hall.

53. Quintilianus, M. (1921). Institutio Oratorio. English trans. H.E. Butler, London.

54. Reynolds, L.D. and Wilson, N. (1974). Scribes and Scholars: A guide to the transmission of Greek and Latin Literature. Oxford: Clarendon Press.

55. Schubert, P. (1943). Book review of Force and Freedom Reflections on History by Jacob Burckhardt. James Hastings Nichols, ed. New York: Pantheon Books, Inc., 1943. In Church History: Studies in Christianity and Culture, 12(2), (pp. 130-131). Available at http://dx.doi.org/10.2307/3159982

56. Scollon, R. (1995). Plagiarism and ideology: identity in intercultural discourse. In Language in Society, 24, (pp. 1-28).

57. Shaka, F. (2005). The Colonial Legacy.History and its Impact of the Development of Modern Culture in Nigeria. In Third Text, 19(3), (pp. 297-305).

58. Smith, J.K. (1983). Quantitative versus qualitative research: An attempt to clarify the issue. In Educational Researcher, 12(1), (pp. 6-13). 
59. Sofowora, O.A. (2012). An Assessment of the Extent of Integration, Application and Utilization of Web-Based Learning Systems in Post Basic Institutions in Nigeria. In Asian Social Science, 8(3), (pp. 317-320).

60. Uzuner, S. (2009). Questions of Culture in Distance Learning: A Research Review. In International Review of Research in Open and Distance Learning, 10(3), (pp. 1-19).

61. van Manen, M. (1997). Researching lived experience: buman science for an action. London, ON: The Althouse Press.

62. van Manen, M. (2007). Phenomenology of Practice. In Phenomenology \& Practice, 1(1), (pp. $11-$ 30).

63. Williams, D. (2010). Dimensions in the Construction of National Identity in Nigeria. In Studies in World Christianity, 16(2), (pp. 169-179).

64. Wiredu, K. (1980). Philosopby and an African Culture. Cambridge: Cambridge University Press. 